\title{
Audit Partner Tenure, Audit Quality and Audit Fees: Evidence from Jordanian Firms
}

\author{
Lina Hani Warrad \\ Accounting Department \\ Applied Science Private University \\ Jordan
}

\begin{abstract}
Audit tenure, audit quality and audit fees are important variables that have been studied and searched on the basis of auditing researches. The current study was conducted on a sample of 30 manufacturing companies listed on Amman Stock Exchange (ASE) from 2011 to 2015; the objective of this study is to examine the correlation between audit fees in these companies and the audit partner tenure (TENURE), on the one hand, and the correlation between audit fees (AUDFEES) and the audit quality (AQ) expressed in Big audit firms (BIG4) in the existence of three control variables; company size (COMPSIZE), return on asset (ROA) and board size (BORDSIZE). The findings of the study resulted in the following: audit partner tenure (TENURE) is an independent variable that is important for the explanation of the Jordanian manufacturing companies' audit fees (AUDFEES), and the audit quality $(A Q)$ is an independent variable that is important for the explanation of the Jordanian manufacturing companies' audit fees (AUDFEES).
\end{abstract}

\section{Introduction}

It should be noted that the auditor's turnover began voluntarily in 1911 when the American company (DuPont) followed the policy of changing its external auditor annually in that period, but in 1939 there were many views on the obligation to change the external auditor such as (Lewis \& Casterell, 1999), because of the great manipulation that occurred in accounts of (McKesson and Robbins) company that called on the US Securities and Exchange Commission (SEC) to conduct several tests to verify the potential and expected benefit of changing the external auditor (Mushtaha, 2014).

In Jordan, the general assembly shall elect one or more auditors licensed to practice the profession, and to perform auditing tasks according to the company's external audit standards, International requirements, professionalism and the ongoing legislation. Auditor should perform audit tasks for one year, renewable, and the engagement partner should not sign up the audit report for more than four consecutive years (https://www.sdc.com.jo). As for the Jordanian Companies Law No. 22 of 1997 in determining the fees of the auditor, Article (192) of the Jordanian Companies Law stipulates that "the General Authority shall be elected by the Public Shareholding Company the Shareholding Company and the Limited Liability Company have audited one or more auditors one year renewable and determined for their remuneration or delegated to the Board of Directors fees. Despite the legal provisions that emphasize the importance of the independence of the auditor, the Jordanian legislator did not pay attention to the bases and criteria that could be used in the process of determining audit fees, except as provided in Article 171 of the Companies Law, which gives the general authority of the company contribute to the election of the company's auditors for the coming year and determine their remuneration or delegation (AlHadweh, 2015).The external auditor provides services in return for fees received from the company, and these fees depend on several factors including the reputation of the audit office and the time spent in the audit process, as well as the efficiency of the internal control system, and the ongoing handling of the audit office with the company. The upgrading of the external audit profession and its clients requires attention to the fees charged which should be proportionate with the effort made in the audit, and otherwise be practical the audit is merely a projection of the imposition by both parties (the external auditor and the company) and thus the process loses its usefulness and importance both to the company and to the beneficiaries from the results of the external audit (AlHadweh, 2015). As for the above, the Board of Directors of the Association of Jordanian Certified Public Accountants had raised the minimum annual fees charged by the legal accountants engaged in the auditing of companies and individuals since the beginning of 2007. 
The Chairman of the Board of Directors of Jordanian Association of Certified Public Accountants Naim Khoury said that the audit fees in Jordan are low, adding that justice would raise the value of fees to reasonable limits for work efforts, increased costs, responsibility and audit risk, allowing legal accountants to enhance their ability to manage on the one hand, and covering the expenses of their programs and computers and introducing them into their daily work (www.addustour.com).

This study will seek to explore the direct impact of the audit partner tenure and audit quality on the audit fees as has been reviewed in many previous literatures, but what distinguishes this study is that two independent variables will be taken, namely the rotation of the partner auditor and the quality of the audit that will be expressed by the Big Four audit firms (BIG4) and will applied on a sample of Jordanian manufacturing companies during a relatively recent period.

\section{Industry in Jordan}

Jordan has a strategic position in the heart of the Middle East, in addition to the stability and security of this small country compared to other neighboring countries. These features have made Jordan a competitive advantage in attracting foreign and domestic investments in various sectors. In addition, the Jordanian government attaches great importance to supporting this sector in various ways, in addition to drawing attention to the enactment of legislation regulating the work in this sector, and working on developing strategies, policies and plans of action to develop the work of the industrial sector. The industry in Jordan is one of the main and important sectors of the national economy. The industrial sector in Jordan contributes directly to economic growth through its absorption of local labor in addition to supporting the balance of payments by increasing government revenues through the tax balance, in addition to this, is working to move many other sectors and participate in supporting the rotation of the wheel of economic growth forward (http://mawdoo3.com). (Rafati, 2018) indicated that the economic growth rate for 2018 was estimated at $2.5 \%$, although it is realistic; however, under fiscal policies that increases taxes, which affect public consumption and investment demand and reduce purchasing power, this means growth and high inflation. According to economic opinions, until the economy reaches the point of equilibrium, the growth rate must exceed $4 \%$, so that the main economic problems can be addressed by reducing deficits, indebtedness, poverty and unemployment (http://www.alghad.com).

\section{Literature Review}

The previous studies will be reviewed by presenting the auditor tenure influence on the audit fees directly and the impact of audit quality on audit fees will presented directly. In the beginning, the studies dealing with the direct relationship in this study will be reviewed, which is the effect of the auditor's turnover on the audit fees.First, in the study of the relation between the auditor's tenure and the audit fees by (Simon, et al., 1988) they noted a decrease in the value of the audit fees when the auditor was assigned in the first year averaging \% 24 , of the standard fee levels for continuing obligations, representing a $\% 15$ reduction in audit fees for each of the next two years, but the arrival of the fourth year with the new auditor make the audit fees rise to the standard audit fees. Also, (Gregory, et al., 1996) discussed that the largest declines in audit fees which related to the size of auditors come from the practice of changing companies to the companies "Big Six." In addition, the investigators pointed that the obligatory changes for the auditor are associated with a positive rise, although there is no statistical significance with the fees, while the auditor's optional changes are associated with negative reductions and material audit fees.

(Gunny, et al., 2007) showed that auditor tenure and industry experience decrease defects for non-Big four audit firms. It shown that auditor's industry expertise is more substantial than auditor tenure to contribute in decreasing defects. Moreover, revealed that auditor's town-level experience has more strength over than country-level experience in decreasing defects. Extraordinary audit fees and total fees are correlated with audit defects and material defects. Also, the interaction of extraordinary audit fees and tenure raises the potential of important defects. Moreover, (Kealey, et al., 2007) showed that there is a positive relation between the audit fees obtained by the new auditor and the extent of the old auditor's period. On the efficiency of the audit market, the positive relation between the current audit fees and the accounts of the previous auditors showed that the new auditors were exposed to greater risk than new customers with a longer period of time with their former auditor. On the other hand, (Laurence, et al., 2007) showed a positive correlation between the specialization and audit quality, but not found with audit fees. 
Moreover, showed that the Big 5 audit firms that oftentimes employed as an indicator for good audit quality in previous studies are not correlated with raised audit quality but systematically charge higher audit fees. Also, (Stanley et al., 2007) found a negative correlation between the auditor tenure period and the potential joining renewal with the company. For short tenure joining, audit and audit earnings are negatively associated with the possibility of renewal with the company. This result is harmonious with worries about lower audit goodness due to shortage of client knowledge and lower audit fees on new audit contracts. Instead, lengthy tenure outcomes display that there is a slight correlation between the non-audit fees and the potential of renewal. This result contrasts with worries about independence over non-audit fees paid to established auditors. Also, (Kwon, et al., 2014) displayed that audit quality did not materially shift match to pre-2006 long-tenure audit positions and optional post-turnover positions. Audit fees in the post-regulation period for obligatorily alternated contracts are materially higher than in the pre-regulation period, but are deducted match to audit fees for post-legislation resuming engagements. Moreover revealed that the spotted rise in audit fees and audit hours in the post-legislation period expand behind positions where the audit firm was obligatorily rotated, proposed that the compulsory audit firm rotation had a much wide effect than the specific instances of mandatory rotation. While, (Choi, 2010) revealed a substantial positive association between the office size and both audit quality and audit fees, even after dominating for national-level audit firm size and office-level industry expertise. These positive correlations advocate the opinion that big local offices supply higher-quality audits compared with small local offices. Moreover, (Nagy, 2014) found a substantive positive association between both audit partner- and office-level specialty and audit fees, and proposed that auditor specialty at both the partner- and local office-level request a fee bonus in the US audit markets. Moreover, the outcomes did not showed a substantial variation between partnerand office-level specialty impacts on audit fees.

The following studies will identify the kind of the relation between audit fees and the fact that the company providing the audit services is classified as a Big Four Firms or otherwise. (Fafatas \& Sun, 2010) suggested that the reputation of each of the Big Four audit firms expressed in the cost of audit fees is not the same in each of these companies. In this study it appeared that what leads to higher audit fees is the quality of audit services provided. (Kikhia, 2015) indicated that there is an irreconcilable association between the auditor tenure, audit risk and audit fees. However, the size of audit appeared to be a key operator in priming audit fees. The researcher also pointed out that there is a negative relation between the financial risks and the audit fees. Also, there is no relation between the auditor tenure and the auditor's fees.

Some literatures linked earnings management as a measurement of the quality of audit with the audit fees, as (Abbott, et al., 2006) showed that sloped earnings management risk, as expressed by negative discretionary accruals, is correlated with minimal audit fees. Also found that high earnings management risk, as expressed by positive discretionary accruals, is correlated with higher audit fees and that the consistency of this risk with an industry-adjusted price-earnings ratio has a progressively material, positive impact on fees. This is also referred to by Nam (2014) who expected a powerful indicator for a positive correlation between the absolute level of discretionary accruals as a measurement of earnings management in the current year, and the audit fees level paid by client in the next year. Otherwise, (Veera, 2015) proposed a negative relation between earnings management through manipulation of sales and overproduction with the audit fees, and that higher quality auditors lowering earnings manipulation pursuits.

(Greiner, et al., 2017) proposed that the participation of real earnings management in auditors' estimations of contracting risk regarding to the client's economic position and lead to a larger audit fees. Moreover, revealed that, with the exception of exceptional decreases in SG\&A, offensive income-growing real earnings management is positively correlated with both current and future audit fees. More analyses provided proofs harmonic with rise attempt joint with raised risk share to the existing pricing impact, with raised business risk firstly leading the future pricing effect. They thus presented proof that offensive income-increasing real earnings management activities have a substantial effect on auditor pricing conduct, harmonic with the audit frame combining joining risk with audit fees.

Also, the previous literatures shows the relationship between partner mandatory tenure periods and earning management as in (Ames et al., 2003) study which used control variables such as age, size, growth, cash flows, and type of external auditor, industry sector, and year. As a general result, it was found that the best quality of profits coincided with the longest audit period of the company's partner auditor. 
The statistical results also revealed that, on average, the current period of auditors' possession has led auditors to place greater limits on immoderate management decisions on reporting financial performance. On the other hand, Jenkins et al. (2008) concluded that the conservatism in earning management does not vary significantly in the long run, either in short and medium tenure, and therefore the change of auditor may have a negative impact on the conservatism of reported profits.

(Chen et al., 2010) showed opposite results for (Ames et al., 2003), where they showed that the absolute and positive values of the discretionary accruals that express the management of earnings are substantially reduced with the tenure of the partner. After monitoring the turnover of the partner, they concluded that the absolute discretionary accruals also decreased significantly with the tenure of the audit firm. These results are not harmonious with discussions and results showing that the quality of earnings decreases with the extension of the period of audit tenures, and that the turnover of the audit company as well as the rotation of partners leads to improved earnings quality. This is also what he reached by (Davis, et al., 2010) who concluded that the when auditor's relationship with the client continued, that the auditor's non-rotation could have a negative influence on audit quality. But may not be generalized, only applies to companies sample study which they are short companies of 2-3 years as well as the long of 13-15 years and more, where these companies are not subjected to the same public pressure to manage earnings in order to meet or override anticipations. While (Chi, et al., 2011) agreed with (Ames et al., 2003) study that the longer the auditor's period of tenure, the better the management of real earnings, which shows and recommends the importance of rotating the auditor of the company. A material negative correlation was found between earnings management and audit quality by (Reyash, 2013), as well as to which there is a association between the external auditor's performance and audit quality, measured by earnings management and the independence of external auditor. Furthermore, (Alzoubi, 2016) showed a material negative relation between audit quality and earnings management. The result concluded that earnings management level is materially less in the companies utilizing the services of independent auditors. Also, the results found that the level of earnings management is materially less between companies contracting a Big 4 audit firm, as compared to firms using the service of a non-Big 4 audit firm. The same idea was proposed by (Lopes, 2018) that there is a correlation between audit quality and earnings manipulation. Also, added that level of earnings management is substantially lower in companies using a Big 4 audit firm, as compared to companies contracting a non-Big 4 audit firm.

\section{Methodology}

\subsection{Study Population, Study Sample and period:}

The study population will include all 62 listed companies listed on the Amman Stock Exchange. The study period will start from 2011 and end in 2015. The analysis will be based on annual reports and financial reports of the sample of 30 industrial companies selected using the stratified sample method for 150 observations. This number of observations constitutes an appropriate number in order to reach the generalization of the results of this study.

\subsection{Study Variables}

In this section, we will identify the independent, dependent, moderator and control variables for the study, and then clarify some of the conventional and procedural definitions of the variables. Also, display the relation between these variables through reviewing the previous theoretical frame work. Finally, we try to formulate the study model as follows:

\section{Independent Variables:}

Audit Partner Tenure (TENURE): as noted previously, the auditor must perform the audit engagements of the company for one year, although the period may be renewed. In addition, the audit partner may not sign the company's audited financial statements for more than four sequential years (https://www.sdc.com.jo). Contenders of involuntary audit-firm rotation suppose that involuntary audit-firm rotation will raise costs afford by both audit firms and auditee companies (Osasu, ET AL., 2017). The audit partner tenure will be measured by the number of years in which the partner auditor signs the audit report of the auditee company. If $>=4$, we set 1 , otherwise 0 .

Turner, A. (2001). "Renewing the covenantwith investors". Speech before the New York University Center for Law and Business

Turner, A. (2001). "Renewing the covenant with investors". Speech before the New York University Center for Law and Business, 
Turner, A. (2001). "Renewing the covenant with investors". Speech before the New York

University Center for Law and Busi

- Audit Quality (AQ): expressed by the Big Four audit firms (BIG4) (Abid, et al, 2018), it is the name of the world's top four accounting and professional services firms, who audit most public shareholding companies, as well as many private companies (https://www.google.com). There also a confidence that Big audit firms supply higher goodness audits than non-Big audit firms because Big audit firms have larger client rules and, thus, have more to lose in the case of loss of reputation that would be correlated with a bad performed audit (Jordan, et al, 2010). In this study BIG4 Indicator variable equal to 1 if the audit firm is big-4, 0 otherwise; A dummy value of 1 is used if a firm uses any of the big 4 auditors and 0 if otherwise.

\section{Dependent variable:}

- Audit Fees (AUDFEES): the audit fees are defined as amounts, or fees charged for the audit engagements of an auditee company's accounts. Fees are determined by contract between the auditee company and the auditor in accordance with the time taken by the audit process and the service required of it, and a practical need checking for assistants (Nijm, 2012). In this study, the audit fees will be defined procedurally for the purposes of measurement and analysis by taking the natural logarithm of the auditor's fees (Naser, et al., 2016).

\section{Control variables:}

- Company Size (COMPSIZE): the size of the auditee company is an significant factor influences the audit fees. In this study, it will be referred to as a control variable to control the association between the audit partner tenure and the audit fees. Some studies have indicated the relation between client's size and audit fees such as (Joshi and Al Bastaki, 2000) who found that audit fees are substantially correlated with the company size. Also, (Carson \& Fargher, 2003) showed that fee premium referred to industry specialist audit firms is massive in the audit fees paid by the slight big clients in each industry. In this study, the size of the company will be measured by taking the natural logarithm of the total assets, (Dang, et al.,2018) utilized three firm size measures: total assets, sales, and equity market value. These measurements are the extreme popular firm size indicators in experimental corporate finance research.

- Return on Asset (ROA): is a measurement of the profitability of a company related to its total assets. The return on assets hand a notion of the management's efficiency in utilizing its assets for profit. The return on assets is calculated by dividing the company's annual profits by its gross assets; it's also named "Return on Investment" (https://trading-secrets.guru/roa). Profitability is a paramount signal of the management's efficiency in managing obtainable resources. The relationship between audit fees and profitability may be either positive or negative. Some may debate that the elevated audit fees that will be incurred by companies that declare a high standard of profit according to strict audit tests to regarding revenue and expenses (Osasu, ET AL., 2017).

- Board Size (BORDSIZE): the board of directors takes decisions that are fundamental to the firm's performance. It is consider as a complementary part of internal governance techniques through which decisions and behavior of managers can be controlled (Isik \& INCE, 2016). Jensen, 1993; Yermack, 1996; Coles; Daniel; and Naveen, 2008, etc. had focused on the size of the Board of Directors (Dang, et al.,2018). In relation to this study, the size of the Board of Directors will be treated as a control variable to control the relation between the audit partner tenure and audit fees, it will expressed by the total number of inside and outside directors on the board of the directors (Isik \& INCE, 2016).

\subsection{Study Model:}

Two models of study will be applied because the study is composed of two independent variables that will be expressed in the dummy variable. In this case, for the purposes of validity of the analysis, two models of the study must be applied. Each model contains one independent variable with the dependent variable and the control variables as follows:

Model 1: AUDFEES $=\beta 0+\beta 1$ TENURE $+\beta 2 A Q+\beta 3$ COMPSIZE $+\beta 4 R O A+\beta 5 B O R D S I Z E+U t$

Model 2: $A U D F E E S=\beta 0+\beta 1 A Q+\beta 2 A Q+\beta 3$ COMPSIZE $+\beta 4 R O A+\beta 5 B O R D S I Z E+U t$

\subsection{Study Hypotheses:}

\subsubsection{Model 1 Hypothesis:}

H1: Audit Partner Tenure is not associated substantially with audit fees 


\subsubsection{Model 2 Hypothesis:}

H2: Audit Quality is not associated substantially with audit fees

\section{Study Results}

\subsection{Descriptive Analysis}

Table1: Descriptive Analysis

\begin{tabular}{|l|l|l|l|l|l|}
\hline Variable & Observations & Mean & Standard Deviation & Minimum & Maximum \\
\hline TENURE & 150 & .3266667 & .4705654 & 0 & 1 \\
\hline AQ & 150 & .42 & .495212 & 0 & 1 \\
\hline COMPSIZE & 150 & 7.350207 & .6876158 & 6.078 & 9.088 \\
\hline ROA & \multicolumn{1}{|c|}{150} & .82368 & 13.7122 & -96.494 & 32.27 \\
\hline BORDSIZE & 150 & 8.4 & 2.833169 & 5 & 23 \\
\hline AUDFEES & 150 & 4.0211 & .3365067 & 3.602 & 4.968 \\
\hline
\end{tabular}

The tests were splited into six accessories which are audit partner tenure, audit quality, company size, return on assets, board size and audit fees. Table1 presents that there is a material domain of differences between some of the chosen samples of this paper. The domain of audit partner tenure (Tenure) is from 0 to 1 with a mean of .3266667 and a standard deviation of .4705654 . The domain of the audit quality (AQ) is from 0 to 1 with a mean of .42 and standard deviation of .495212. Also, the assumed control variables for company size (COMPSIZE) is from 6.078 to 9.088 , with a mean of 7.350207 , and standard deviation of .6876158 and the domain of return on assets (ROA) are from -96.494 to 32.27 , with a mean of .82368 and a standard deviation of 13.7122 . Finally for the audit fees (AUDFEES) is from 5 to 23 with a mean of 8.4 and a std. of 2.833169

\subsection{Correlations}

Table2: Pearson's Correlation Coefficient- Model 1

AUDFEES $=\beta 0+\beta 1$ TENURE $+\beta 2 A Q+\beta 3$ COMPSIZE $+\beta 4 R O A+\beta 5 B O R D S I Z E+U t$

\begin{tabular}{|l|ccccc|}
\hline Variables & TENURE & COMPSIZE & ROA & BORDSIZE & AUDFEES \\
\hline TENURE & 1.0000 & & & & \\
\hline COMPSIZE & -0.0471 & 1.0000 & & & \\
\hline ROA & -0.1153 & 0.4359 & 1.0000 & & \\
\hline BORDSIZE & -0.1138 & 0.5307 & 0.1317 & 1.0000 & 1.0000 \\
\hline AUDFEES & 0.0045 & 0.8110 & 0.2465 & 0.4208 & \\
\hline
\end{tabular}

Correlation analysis was utilized for the purpose of understand the grade of association through the variables in this paper which ranges from +1 to -1 . Refer to table 2 , we enable to realize that there is sturdy associations between some variables with a positive signal, which point that the positive relation through these variables is go up, on the other hand, there is a weak association through some other variables, and either this direction is positive or negative.

Table3: Pearson's Correlation Coefficient- Model 2

AUDFEES $=\beta 0+\beta 1 \mathrm{AQ}+\beta 2 \mathrm{AQ}+\beta 3 \mathrm{COMPSIZE}+\beta 4 \mathrm{ROA}+\beta 5 \mathrm{BORDSIZE}+\mathrm{Ut}$

\begin{tabular}{|l|ccccc|}
\hline Variables & AQ & COMPSIZE & ROA & BORDSIZE & AUDFEES \\
\hline AQ & 1.0000 & & & & \\
\hline COMPSIZE & 0.3462 & 1.0000 & & & \\
\hline ROA & 0.1021 & 0.4359 & 1.0000 & & \\
\hline BORDSIZE & 0.2717 & 0.5307 & 0.1317 & 1.0000 & 1.0000 \\
\hline AUDFEES & 0.5643 & 0.8110 & 0.2465 & 0.4208 & \\
\hline
\end{tabular}

Correlation analysis was utilized for the purpose of understand the grade of association through the variables in the two models in this paper which ranges from +1 to -1 . Refer to table 2 and table3, we enable to realize that there is sturdy associations between some variables with a positive signal, which point that the positive relation through these variables is go up, on the other hand, there is a weak association through some other variables, and either this direction is positive or negative.

\subsection{Testing the Study Hypotheses:}

H1: Audit Partner Tenure is not associated substantially with audit fees 
Table4: Testing for Hypothesis 1-Model 1

AUDFEES $=\beta 0+\beta 1$ TENURE $+\beta 2 A Q+\beta 3$ COMPSIZE $+\beta 4 R O A+\beta 5 B O R D S I Z E+U t$

\begin{tabular}{|c|c|c|c|c|c|c|c|}
\hline Source & SS. & df. & MS. & \multicolumn{4}{|c|}{ No. of observations $=150$} \\
\hline & & & & \multicolumn{2}{|c|}{$\mathrm{F}(6,26)$} & 74.7 & \\
\hline Model & 11.3598747 & 4 & 2.83996867 & \multicolumn{2}{|c|}{ Prob > F } & $=0.0000$ & \\
\hline Residual & 5.51240683 & 145 & .038016599 & \multicolumn{2}{|c|}{ R-squared } & $=$ & 0.6733 \\
\hline & & & & \multicolumn{2}{|c|}{ Adj R-squared } & $=0.6643$ & \\
\hline Total & $\mathbf{1 6 . 8 7 2 2 8 1 5}$ & 149 & .113236789 & \multicolumn{2}{|c|}{ Root MSE } & $=$ & .19498 \\
\hline AUDFEES & Coefficient & Std. Error & $\mathbf{t}$ & $\mathbf{P}>|\mathbf{t}|$ & {$[95 \%$ Conf. } & Interval] & \\
\hline $\begin{array}{l}\text { TENURE } \\
\text { COMPSIZE }\end{array}$ & .0197986 & .0344229 & 0.58 & 0.566 & -.0482368 & .0878341 & \\
\hline COMPSIZE & .4331117 & .030519 & 14.19 & 0.000 & .372792 & .4934314 & \\
\hline ROA & -.0032495 & .0013152 & -2.47 & 0.015 & -.0058489 & -.0006502 & \\
\hline BORDSIZE & -.0033642 & .0067587 & -0.50 & 0.619 & -.0167225 & .0099941 & \\
\hline _cons & .8621077 & .1998883 & 4.31 & 0.000 & .4670366 & 1.257179 & \\
\hline
\end{tabular}

By initiating the above results, we can observe that R-squared 0.6733 is more than 0.60 , which drove to that the data of this model is extremely suited, as well as that 0.6733 percent deviations in audit fees (AUDFEES) via three control variables: company size (COMPSIZE), return on asset (ROA) and board size (BORDSIZE), can be described by audit partner tenure (TENURE). So, the residual percent deviations in audit fees (AUDFEES) can be described by other variables differently than audit partner tenure (TENURE)

H1: Audit Partner Tenure is not associated substantially with audit fees

After reading the probability value of audit partner tenure (TENURE) which is 0.0000 below 0.05 , it notice that through three control variables: company size (COMPSIZE), return on asset (ROA) and board size (BORDSIZE), audit partner tenure (TENURE) is an materialistic variable to explain audit fees (AUDFEES), thus the null hypothesis should be not accepted, but accept the alternative hypothesis that audit partner tenure (TENURE) is associated basically with audit fees through company size (COMPSIZE), return on asset (ROA) and board size (BORDSIZE). This results is convenient with (Kealey, et al., 2007), and inconvenient with (Kikhia, 2015), It is thus likely to conclude that the audit partner tenure (TENURE) is an independent variable that is important for the explanation of the Jordanian manufacturing companies' audit fees (AUDFEES).

H2: Audit Quality is not associated substantially with audit fees

Table5: Testing for Hypothesis 2-Model 2

AUDFEES $=\beta 0+\beta 1 \mathrm{AQ}+\beta 2 \mathrm{AQ}+\beta 3 \mathrm{COMPSIZE}+\beta 4 \mathrm{ROA}+\beta 5 \mathrm{BORDSIZE}+\mathrm{Ut}$

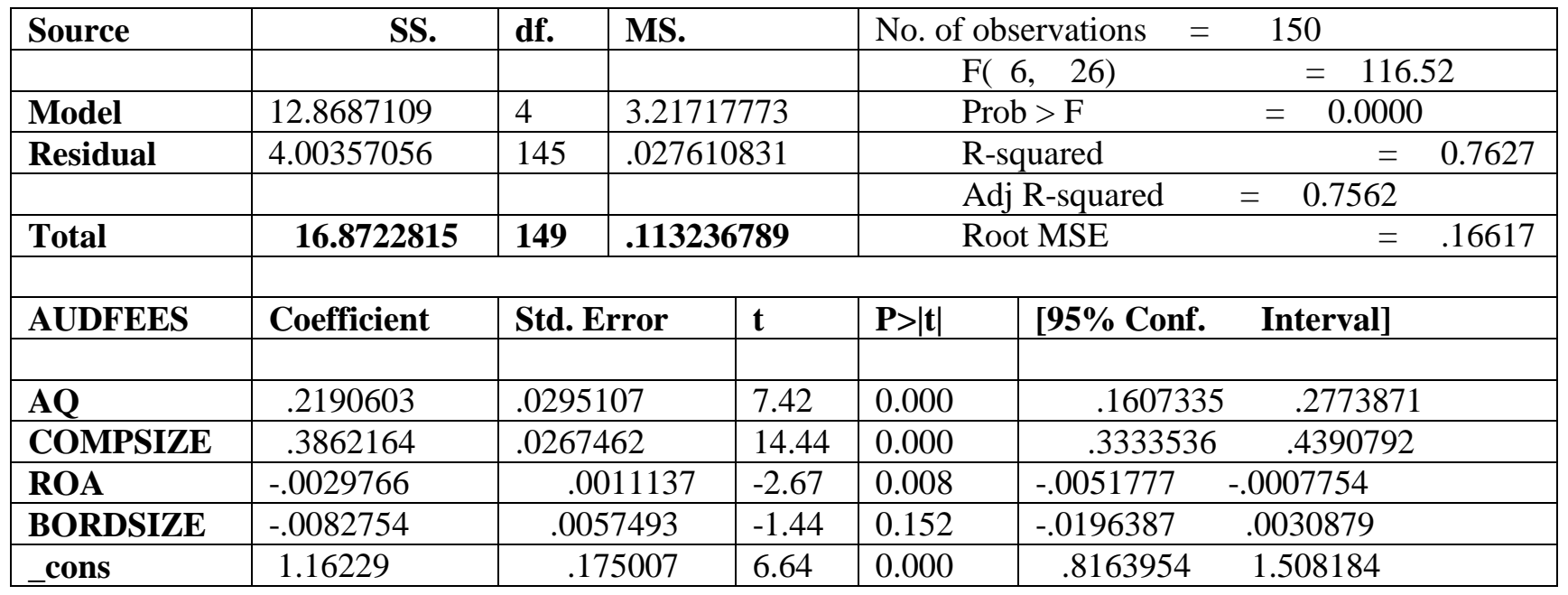


By initiating the above results, we can observe that R-squared 0.7627 is more than 0.60 , which drove to that the data of this model is extremely suited, as well as that 0.7627 percent deviations in audit fees (AUDFEES) via three control variables: company size (COMPSIZE), return on asset (ROA) and board size (BORDSIZE), can be described by audit quality (AQ) that expressed by Big audit firms (BIG4). So, the residual percent deviations in audit fees (AUDFEES) can be described by other variables differently than audit partner tenure audit quality (AQ).

H2: Audit Quality is not associated substantially with audit fees

After reading the probability value of audit quality (AQ) which is 0.0000 below 0.05 , it notice that through three control variables: company size (COMPSIZE), return on asset (ROA) and board size (BORDSIZE), audit quality (AQ) is an materialistic variable to explain audit fees (AUDFEES), thus the null hypothesis should be not accepted, but accept the alternative hypothesis that audit quality (AQ) which is expressed by Big audit firms (BIG4) is correlated basically with audit fees through company size (COMPSIZE), return on asset (ROA) and board size (BORDSIZE). This results is convenient with (Fafatas \& Sun, 2010), (Gregory, et al., 1996) and (Laurence, et al., 2007), and inconvenient with (Lopes, 2018), It is thus likely to conclude that the audit quality (AQ) is an independent variable that is important for the explanation of the Jordanian manufacturing companies' audit fees (AUDFEES).

\section{Results Discussions}

The findings of the analysis can be summarized between compatible and incompatible with the outcomes of preceding studies. The results showed that there is a strong relation between the audit partner tenure (TENURE) and the audit fees (AUDFEES) on the one hand, as well as a very strong relation between the audit quality measured by the Big audit firms (BIG4) and the audit fees (AUDFEES). These results was compatible with what mentioned in the survey, which is published in the June of 2018 issue of the American Accounting Association's Accounting Horizons, concluded that Big Four audit fees raises by an average of $13 \%$ between the first and second year of tenure and by around $22 \%$ between the first and third year, by year 12 the fees are usually around $28 \%$ above the original fee and $32 \%$ above it by year 14 . The academics established that this style of fee raise is limited to the Big Four. Among the hundreds of other firms in the research, audit fees act to stay level or even decrease the longer the audit engagement continues (https://economia.icaew.com).

\section{References}

Abbott, L., Parker, S., Peters, G., (2006). "Earnings Management, Litigation Risk, and Asymmetric Audit Fee Responses", AUDITING: A Journal of Practice \& Theory, Vol. 25, No. 1, pp. 85-98. https://doi.org/10.2308/aud.2006.25.1.85

Abid, A., Shaique, M., Ul Haq, M., (2018). "Do Big Four Auditors Always Provide Higher Audit Quality? Evidence from Pakistan", International Journal of Financial Studies, 6, 58, pp.1-22.

Al-Hadweh, Z., (2015). "Factors Affecting The Audit Fees: An Empirical Study on Auditing Firms at The Hashemite kingdom of Jordan", this thesis is an update of the requirements for obtaining a Master's degree in Accounting, Accounting and Finance Department, Business School, Middle East University, pp. 1-85.

Alzoubi, E., (2016). "Audit quality and earnings management: evidence from Jordan", Journal of Applied Accounting Research, Vol. 17 Issue: 2, pp.170-189, https://doi.org/10.1108/JAAR-09-2014-0089

Ames N. Myers, Linda A. Myers, and Thomas C. Omer. (2003). "Exploring the Term of the Auditor_Client Relationship and the Quality of Earnings: A Case for Mandatory Auditor Rotation?",The Accounting Review, Vol. 78, No. 3, pp. 779-799.

Bhagat, Sanjai and Bolton, Brian J., (2012), “ Director Ownership, Governance and Performance”, Available at SSRN: https://ssrn.com/abstract=1571323 or http://dx.doi.org/10.2139/ssrn.1571323

Brooks, Z., (2011), “Auditor tenure and audit quality", LSU Doctoral Dissertations, Louisiana State University and Agricultural and Mechanical College, lbrook2@tigers.lsu.edu.

Carson, E., Fargher, N., (2003). "The impact of client size on the estimation of audit fee premiums attributed to industry specialization", Accounting and Finance, Vol. 47, Issue 3, pp. 423-446

Chen, C., Lin, C., Lin, Y., (2010). “Audit Partner Tenure, Audit Firm Tenure, and Discretionary Accruals: Does Long Auditor Tenure Impair Earnings Quality?", Contemporary Accounting Research, Volume25, Issue2,https://doi.org/10.1506/car.25.2.5 
Chi, W., Lisic, L., Pevzner, M., (2011). "Is Enhanced Audit Quality Associated with Greater Real Earnings Management?", Accounting Horizons:, Vol. 25, No. 2, pp. 315-335. https://doi.org/10.2308/acch-10025

Choi, J., Kim, C., Kim, J., Zang, Y., (2010). “Audit Office Size, Audit Quality, and Audit Pricing”, AUDITING: A Journal of Practice \& Theory, Vol. 29, No. 1, pp. 73-97. https://doi.org/10.2308/aud.2010.29.1.73

Dang, C., Li, Z., Yang, C., (2013). "Measuring Firm Size in Empirical Corporate Finance", Journal of Banking and Finance, Forthcoming, Available at

SSRN: https://ssrn.com/abstract=2345506 or http://dx.doi.org/10.2139/ssrn.2345506

Davis, L., Soo, B., Trompeter , G.,(2010). "Auditor Tenure and the Ability to Meet or Beat Earnings Forecasts",Contemporary Accounting Research, Vol. 26, Issue 2, pp.517-548. https://doi.org/10.1506/car.26.2.8

Fafatas, S, Sun,K., (2010). "The relationship between auditor size and audit fees: further evidence from big four market shares in emerging economies, in Mathew Tsamenyi, Shahzad Uddin (ed.)", Research in Accounting in Emerging Economies, Volume 10, Emerald Group Publishing Limited, pp.57 - 85

Gregory, A., Collier, P., (1996). AUDIT FEES AND AUDITOR CHANGE; AN INVESTIGATION OF THE PERSISTENCE OF FEE REDUCTION BY TYPE OF CHANGE, Journal of Business Finance \& Accounting, Volume23, Issue1, https://doi.org/10.1111/j.1468-5957.1996.tb00399.x

Greiner,A., Mark J. Kohlbeck M., Smith, T.,(2017). "The Relationship between Aggressive Real Earnings Management and Current and Future Audit Fees", AUDITING: A Journal of Practice \& Theory, Vol. 36, No. 1, pp. 85-107. https://doi.org/10.2308/ajpt-51516

Gunny, Katherine, and Krishnan, Gopal, V., Zhang, Tracey Chunqi, (2007). "Is Audit Quality Associated with Auditor Tenure, Industry Expertise, and Fees? Evidence from PCAOB Opinions", Available at, SSRN: https://ssrn.com/abstract=10150 or89 http://dx.doi.org/10.2139/ssrn.1015089.

Isik, O., INCE, A., (2016). "Board Size, Board Composition and Performance: An Investigation on Turkish Banks", International Business Research9, (2):74 .

Jenkins, D., Velury, U., (2008). "Does Auditor Tenure Influence The Reporting of Conservative Earnings?", Journal of Accounting and Public Policy, Volume 27, Issue 2, PP. 115-132. https://doi.org/10.1016/j.jaccpubpol.2008.01.005

Jordan, C., Clark, S., Hames, C., (2010). "The Impact of Audit Quality On Earnings Management To Achieve User Reference Points In EPS", The Journal of Applied Business Research, Volume 26, Number 1, pp. 19-30

Joshi, P. L., Al Bastaki, H., (2000). "Determinants of Audit Fees: Evidence from the Companies Listed in Bahrain", International Journal of Auditing, Vol. 4, Issue 2, https://doi.org/10.1111/1099-1123.00308

Kealey, B., Lee, H., Stein, M., (2007). "The Association between Audit-Firm Tenure and Audit Fees Paid to Successor Auditors: Evidence from Arthur Andersen". AUDITING, A Journal of Practice \& Theory, Vol. 26, No. 2, pp. 95-116. https://doi.org/10.2308/aud.2007.26.2.95

Kikhia, H., (2015), "Determinants of Audit Fees: Evidence from Jordan", Accounting and Finance Research, Vol. 4, No. 1, PP. 42-53.

Kwon, S., Lim, Y., Simnett, R., (2014). "The Effect of Mandatory Audit Firm Rotation on Audit Quality and Audit Fees: Empirical Evidence from the Korean Audit Market", AUDITING: A Journal of Practice \& Theory, Vol. 33, No. 4, pp. 167-196. https://doi.org/10.2308/ajpt-50814

Laurence, S., Randal, E., Stephen, J., Davies, P., (2007). "Auditor specialization, perceived audit quality, and audit fees in the local government audit market", Journal of Accounting and Public Policy, Volume 26, Issue 6, PP. 705-732. https://doi.org/10.1016/j.jaccpubpol.2007.10.004

Lopes, A., (2018). "Audit Quality and Earnings Management: Evidence from Portugal", Athens Journal of Business \& Economics, Volume 4, Issue 2, pp.179-192. DOI=10.30958/ajbe.4.2.4

Mushtaha, S., (2014). "Analysis of the Relationship between the Auditor Rotation and Quality of the External Audit and its Impact on the Opinion of the External Auditor", Journal of the Islamic University for Economic and Administrative Studies, Vol. 22, No. 2, pp. 1-62.

Nagy, A., (2014). Audit partner specialization and audit fees, Managerial Auditing Journal, Vol. 29, No. 6, pp. 513-526, DOI 10.1108/MAJ-11-2013-096.

Nam, L., (2014). "Earnings Management and Audit Fee Responses in New Zealand", Financial Markets \& Corporate Governance Conference. http://www.fmcgc2014.qut.edu.au 
Naser, K., Hassan, Y., (2016). "Factors influencing external audit fees of companies listed on Dubai Financial Market", International Journal of Islamic and Middle Eastern Finance and Management, Vol. 9 Issue: 3, pp.346-363. https://doi.org/10.1108/IMEFM-01-2015.

Nijm, M., (2012)," In Determining the Fees Factors Affecting of the External Auditors in the Gaza Strip", this thesis is an update of the requirements for obtaining a Master's degree in Accounting, Islamic University - Gaza, Deanship of Graduate Studies, Faculty of Commerce, Accounting and Finance Department, PP.1-133.

Osasu, O., Okaiwele, Mavis, I, (2017). "AUDITOR TENURE AND AUDIT FEE: A GRANGER CAUSALITY Analysis Approach", Sokoto Journal of the Social Sciences, Volume 7. NO.2, 10.29816/sjss.7.2.19 DOI:

Reyash, A., (2013). "The effect of mandatory rotation of the external auditor on audit quality Applied Study on Corporations Listed on Palestine Exchange", Master Thesis, this thesis is a requirements for obtaining a master's degree, Islamic University, PP.1-130.

Simon, T., Francis , J., (1988). "The Effects of Auditor Change on Audit Fees: Tests of Price Cutting and Price Recovery", The Accounting Review, Vol. 63, No. 2, pp. 255-269.

Stanley, J., DeZoort , F., (2007). "Audit firm tenure and financial restatements: An analysis of industry specialization and fee effects", Journal of Accounting and Public Policy, Volume 26, Issue 2, pp. 131159.

Veera, N., (2015). "The effect of earnings management on audit fees, Evidence from the manufacturing industry", Accounting Master's thesis, Department of Accounting, Aalto University School of Business, PP.1-64.

\section{Other:}

https://www.sdc.com.jo/arabic/index.php?option=com_content\&task=view\&id=882. 27/6/2018, 10:15. http://mawdoo3.com., 12/7/2018, 8:38.

http://www.alghad.com/articles/2028102., 12/7/2018, 9:24

https://www.addustour.com/articles/308333, 30/9/2018, 8:30

https://trading-secrets.guru/roa, 1/10/2018, 6:50

https://www.google.com/search?source=hp\&ei=ofyyW5zyOuLjkgWE6pLQDg\&q, 2/10/2018, 8:40

https://economia.icaew.com/news/may-2018/big-four-in-us-use-lucrative-audit-fee-structure,10/10/2018, 10:53. 